\title{
The British Anti-Apartheid Movement and Political Prisoner Campaigns, 1973-1980
}

\author{
GENEVIEVE KLEIN
}

(University of Oxford)

This article analyses selected Anti-Apartheid Movement (AAM) activities designed to publicise political prisoners and detainees. The political prisoner campaign was one way in which the AAM highlighted the role of the liberation movements fighting apartheid. It illustrates how the AAM not only played a key part in exposing the immorality of apartheid, but also in popularising the liberation movements, and especially the African National Congress (ANC). All AAM activity broadly supported the liberation movements, informed British public opinion on conditions in South Africa, and aimed to change British government policy. However, certain actions focused more specifically on popularising the liberation movements and specific members in these movements. Political prisoner campaigns showed the difficulties faced by specific people caught up in the South African judicial system and the way in which the South African government used trials and jail sentences to weaken the liberation movements. On the one hand, the AAM attempted to highlight the activity of the liberation movements inside South Africa and the violence of the South African regime. On the other hand, it appealed to international concerns about human rights. The AAM aimed to invert the idea that the liberation movements were primarily responsible for violence through focusing on violence by the regime. Of all the campaigns for individual prisoners, that for Nelson Mandela achieved the highest profile. These campaigns were effective in increasing international criticism of apartheid and provided an opportunity for many concerned about human right to take a stand against apartheid.

\section{Introduction}

The British Anti-Apartheid Movement (AAM) was founded in London in April 1960 and while it did not initiate anti-apartheid action in Britain, it brought together different activities in the aftermath of the Sharpeville Massacre of 21 March 1960. The presence of many South African exiles and radical Anglican Churchmen in the United Kingdom (UK) led to a growing concern for South African racial issues in the period preceding Sharpeville. The Boycott Movement, the 
predecessor of the AAM, publicised apartheid, encouraged the boycott of South African products, and established links with political parties and concerned groups, which proved important for the AAM. The AAM was a broad-based movement which aimed to work with people from diverse backgrounds and all political parties. It used various strategies and focused on different aspects of apartheid. The AAM wanted to change British government policy, influence and inform British public opinion, and support the South African liberation movements. ${ }^{1}$

This article discusses one aspect of AAM anti-apartheid activity - campaigns in support of South African political prisoners and detainees and the attendant campaigns against human rights abuses. Through these campaigns, which became increasingly important in the later apartheid years, the AAM succeeded in attracting broader public support for anti-apartheid campaigns than would have been the case had it restricted itself to political debates. Human rights issues also succeeded, on occasion, in attracting support from the British government and other world organisations and allowed for the AAM to establish new networks. In this article, I start by outlining the focus on human rights issues in the struggle against apartheid. The next section describes the development of the AAM campaign for political prisoners, firstly during the Rivonia Trial and then, in 1973, with the formation of 'Southern Africa: The Imprisoned Society (SATIS)'. Finally, I discuss campaigns taken up by SATIS in the period 1973 to 1980, and the start of the Campaign to free Nelson Mandela. Through analysing these campaigns it becomes clear that AAM support for all South African movements was not equal. The AAM increasingly favoured the African National Congress (ANC) over other South African liberation movements when choosing which political prisoners and human rights abuses around which to mobilise support. Furthermore, by considering the discussions around campaigns it is clear that the ANC was consulted more than other groups and that its priorities were emphasised. I suggest that while political prisoner and human rights campaigns proved highly successful in attracting support for the anti-apartheid struggle, this support became centred on the ANC as the primary South African liberation movement.

\section{Human Rights and the Anti-Apartheid Struggle}

\footnotetext{
${ }^{1}$ R. Fieldhouse, Anti-Apartheid: A History of the Movement in Britain (London, Merlin, 2005), pp. 1-22; C. Gurney, “"A Great Cause”: The Origins of the AAM, June 1959-March 1960', Journal of Southern African Studies (hereafter JSAS) 26, 1 (March 2000), pp. 131-2; M. Israel, South African Political Exile in the UK (London, Macmillan, 1999), pp. 158-67.
} 
Human rights issues were of particular importance in the international struggle against apartheid considering the prominence of these issues internationally and the possibility for the building of networks between anti-apartheid solidarity groups and other concerned movements. After the Second World War the focus on human rights increased world-wide and led to increased awareness of discrimination and just legal process. After the Universal Declaration of Human Rights was adopted by the United Nations (UN) in 1948, there was an expectation that a regime, whatever its ideology, should adhere to certain, universal norms. It was in this international climate that South Africa introduced apartheid in 1948. Meanwhile, the issues of torture and detention became international concerns. In 1961 Amnesty International was formed by Peter Benenson, a human rights lawyer, when he launched 'An Appeal for Amnesty, 1961'. Amnesty chose a position of 'impartiality' on questions of political ideology and selected prisoners from both the East and West during the Cold War, but stressed the importance of non-violence in its selection of so-called 'Prisoners of Conscience'. Martin Ennals, ex-AAM Organising Secretary, took over the leadership of Amnesty International in 1969. The growing stature of human rights issues was evident when Amnesty International obtained observer status at the UN and was awarded the Nobel Prize in $1977 .^{2}$

Well before the formation of the AAM and before the International Commission of Jurists (ICJ) brought out a report condemning apartheid and informing the international community of its 'full legal and moral implications', issues of torture and imprisonment in South Africa were the subject of international attention. ${ }^{3}$ But the Sharpeville Massacre was a turning-point and led to international condemnation of apartheid and public awareness of the reality of the South African situation. Much of the condemnation was based on human rights grounds. ${ }^{4}$ In 1965 the UN drew up a document on the rights of arrested people inside South Africa, which it gave to the South African government, making the government aware that its treatment of prisoners did not conform to international norms. ${ }^{5}$

The AAM's focus on political prisoners and human rights allowed for networks to be formed with other concerned parties. The AAM and Amnesty International established good

\footnotetext{
2 J. Power, Like Water on a Stone. The Story of Amnesty International (London, Penguin, 2002).

${ }^{3}$ H. Deegan. The Politics of the New South Africa. Apartheid and After (Essex, Pearson Education, 2001 ), pp. 33-4.

${ }^{4}$ P. Frankel, An Ordinary Atrocity. Sharpeville and its Massacre (New Haven/London, Yale University Press, 2001).

${ }^{5}$ National Archive, Pretoria (SAB): BVV28 (11/4/3/2): Freedom from arbitrary arrest, detention and exile: UN document 14 Jan. 1965, government response.
} 
relations, although they clashed over the issue of armed struggle. Amnesty International chose not to declare Mandela a Prisoner of Conscience as a result of his participation in the formation of Umkhonto we Sizwe (MK), the armed wing of the ANC, while the AAM believed that its role was merely to provide solidarity with those struggling against apartheid. ${ }^{6}$ Nevertheless, Amnesty International and the AAM collaborated on numerous campaigns focused on detention and torture in South African prisons.

Judicial and human rights issues also led to contact between the AAM and the UN in its role as guardian of human rights. The issue of segregation in South Africa was already brought before the UN in June 1946 by the Indian government, which then proceeded to criticise apartheid and call for condemnation of the policy in 1948. ${ }^{7}$ After the Sharpeville massacre the UN started paying more attention to South Africa and the Security Council condemned apartheid, although prominent members, such as Britain and France, abstained on resolutions. The need for better reporting on apartheid was recognised, and when a sanctions resolution was passed in November 1962 the resolution included a section calling for the establishment of a committee to keep track of developments in South Africa. However, because the committee had been formed as part of a resolution on sanctions, it was boycotted by Western countries. E.S Reddy, a UN official, became Secretary of the Special Committee Against Apartheid and later Director of the Centre Against Apartheid. In 1963 Reddy reacted to reports of the Rivonia Trial and arranged for ANC President, Oliver Tambo, to address the UN Special Political Committee. ${ }^{8}$ On 8 October 1963 Tambo spoke on the subject of South African political prisoners and three days later, on 11 October, the UN General Assembly passed Resolution 1881 requesting that the South African Government abandon the Rivonia trial and grant unconditional release to all political prisoners and other persons restricted for opposing apartheid. ${ }^{9}$ The anniversary of the Resolution became

\footnotetext{
${ }^{6}$ Power, Like Water on a Stone, pp. 125-6; interview with Dominic Tweedie, 30/11/2004, Johannesburg, (AAM Committee Member).

${ }^{7}$ E.S Reddy, 'United Nations and Apartheid - A Chronology’, available at http://www.anc.org.za/un/un-chron.html, retrieved 11 April 2008.

${ }^{8}$ N. M. Stultz, 'Evolution of the UN Anti-apartheid Regime' Human Rights Quarterly, 13 (1991), pp. 1-23; interview with Abdul Minty, 10 Jan. 2005, Pretoria, (AAM Honorary Secretary); interview with Mac Maharaj, 6 Jan. 2005, Johannesburg, (ANC NEC member); Reddy, 'AAM and UN: Partners in the International Campaign Against Apartheid' at 'The AAM: A 40-year Perspective’ London, 1999; D. Herbstein, White Lies. Canon Collins and the Secret War Against Apartheid (Cape Town, HSRC Press, 2004), pp.100-06; 'E.S. Reddy page: Articles, Papers and Speeches’, available at http://www.anc.org.za/un/reddy/\#COLLECTIONS, retrieved 12 April 2007.

9 A. Tambo (compiler), Preparing for Power: Oliver Tambo Speaks (London, Heinemann African Writers Series 1987), pp. 42-6.
} 
the Day of Solidarity with South African Political Prisoners and was commemorated annually by the AAM.

Contact between the AAM and UN became more formalised after the formation of the UN Special Committee Against Apartheid. The two groups were in constant contact and the Special Committee came to rely on the AAM for information and campaign initiatives while the Special Committee provided the AAM with international access and, on occasion, funding. This close relationship extended the influence and impact of the AAM.

Campaigns focusing on political prisoners and human rights also led to the AAM working closely together with liberation movements and solidarity movements. The International Defence and Aid Fund (IDAF) had, since its founding, focused on prisoners and trials. During the 1956 Treason Trial, John Collins began collecting money for the legal defence of those accused of political participation. As repression and trials continued the need for a permanent and international body was recognised, and IDAF was formed. ${ }^{10}$ IDAF focused on supporting, through the provision of lawyers, those on trial and their dependents. Furthermore, IDAF gathered and published information on South African political prisoners and the conditions to which they were subjected. While IDAF supported political trials across ideological divides, it faced a problem with the Pan Africanist Congress (PAC). When PAC President, Robert Sobukwe, was brought before the court he refused to plead, pay bail or offer a defence. Other PAC accused followed this precedent and refused to participate in the legal process, declaring the court illegitimate and unrepresentative. This meant that IDAF could not intervene by providing legal support. ${ }^{11}$ While rejecting the court process never became a universal trend, the number of accused who refused to participate in the legal proceedings increased in the late 1970s and 1980s and came to include ANC and United Democratic Front (UDF) supporters. This development emphasised the need for an alternative means of international solidarity and a rejection of the legitimacy of the South African legal process.

It was mainly through IDAF and the liberation movements that the AAM accessed information on trials, torture, prisoners and conditions. The relationship between the AAM and IDAF however remained uneasy as they often struggled for support from the same British constituency. It was in close collaboration with the liberation movements that the AAM selected

\footnotetext{
${ }^{10}$ Herbstein, White Lies; Mayibuye Archive, University of the Western Cape (UWC): MCA5-171cc (IDAF Collection) Huddleston/J.Collins Interview.

${ }^{11}$ Herbstein, White lies, pp. 47-8; J. Hoogendyk, According to My Beliefs (Banbury, Counterpoint ,1995), p. 140.
} 
which trials to publicise. An analysis of these campaigns therefore also sheds light on the nature of the relationship between the AAM and the liberation movements. The choice of campaigns and discussions around selecting campaigns demonstrated a clear focus on the ANC, and later the UDF. $^{12}$

While the ANC provided the AAM with much of its information, the close relationship with the ANC also led to some criticism of the AAM. Mac Maharaj explained that proposals for campaigns were not imposed on the AAM, but came out of debates and discussions with the ANC. ${ }^{13}$ However, there were complaints about a bias towards the ANC. This was the case, for instance, with the trial of the 'Upington 14' in the 1980s. Aubrey Beukes from Upington met with the ANC, AAM and SATIS and reported that the Upington community felt isolated from the campaign for the 'Upington 14', and 'felt those abroad who wished to help then were PAC or [Black Consciousness Movement] BCM orientated'. They were upset that SATIS focused only on 'patriots'. 14 This shows the difficulty the AAM faced in selecting trials and accessing information. The AAM took up the case of the Upington 14, but their partiality continued to be questioned.

The focus on the ANC was also criticised by Joyce Mokhesi-Parker, who described her attempts to start a campaign for the 'Sharpeville 6' in the 1980s. Her brother was among the six and she knew that the accused were not politically aligned and wished to remain so. However, many UK student unions were ANC-aligned and refused to take up the case without instructions from the ANC. Solly Smith, the ANC London representative, refused to participate unless the ANC could adopt the prisoners. Even the British Labour Party expressed sympathy but did not get involved. However, after addressing the UN Special Committee in 1986 the campaign was taken up and by April 1986 it was an AAM priority. Mokhesi-Parker later expressed appreciation for the amount of support she got from SATIS. ${ }^{15}$

Aside from the close relations formed with the UN, IDAF and concerned groups, human rights issues also gave the AAM greater access to the British government, which was more approachable about narrower issues of legal process and human rights even though it was

\footnotetext{
${ }^{12}$ Herbstein, White Lies, p. 291; interview with Horst Kleinschmidt, 12/10/2004, Durban, (IDAF and ANC member); interview with Shanti Naidoo, 24 Nov. 2004, Johannesburg (AAM and ANC); e-mail contact with Howard Smith, 25 Oct. 2004, (AAM member).

${ }^{13}$ Interview Maharaj, 6 Jan. 2005, Johannesburg.

${ }^{14}$ Rhodes House, Oxford, Archive of the AAM (MSSAAM) 1796: SATIS Minutes 1988-1989: 30 April 1990.

${ }^{15}$ P. Parker \& J. Mokhesi-Parker, In the Shadow of Sharpeville (London, Macmillan, 1998), pp. 260-61, 265-70.
} 
reluctant to lend direct support to the liberation movements. This was especially the case after 1979 when Margaret Thatcher became Prime Minister. She was prepared, on occasion, to support specific campaigns to save the lives of political prisoners on death row or those in jail, but would not meet with the ANC and was critical of the armed struggle. Campaigns for political prisoners therefore, on occasion, gave the AAM direct access to the British government, despite the fact that the campaigns were not always successful in stopping hangings or imprisonment. The AAM tactic of focusing on prisoners, trials and human rights became increasingly important as the AAM tried to encourage government intervention and the moral rejection of apartheid. ${ }^{16}$ The AAM found that emphasising individual cases stressed the violence of the South African regime and the level of resistance by its citizens. In attracting worldwide support in these battles against the state, international human rights norms increasingly came to be applied to the South African government and critics demanded that these norms be adhered to. The treatment of prisoners and wide use of torture and execution also negated South African government attempts at claiming reform by publicising continued repression inside the country. ${ }^{17}$

\section{The World Campaign for the Release of South African Political Prisoners}

The AAM focus on political trials and prisoners began in August 1962, when Mandela was arrested, and intensified during the Rivonia Trial of 1963-1964. In October 1963 members of the AAM, IDAF, Africa Bureau and Christian Action met to discuss a campaign around the Rivonia Trial. They formed the World Campaign for the Release of South African Political Prisoners. ${ }^{18}$ Although the World Campaign was primarily concerned to raise awareness about the Rivonia Trial, it reported more widely on other political trials, deaths in detention, and the use of torture by South African authorities. The British government was initially cautious about the campaign, but UN support made it more acceptable. A petition with over 180,000 signatures was handed to the UN to try and save the lives of the Rivonia accused. The ANC worked closely with the World Campaign and thanked it for its help in raising support in other European countries. Robert Resha

\footnotetext{
${ }^{16}$ Interview with Toine Eggenhuizen, 22 November 2004, Johannesburg (IDAF).

${ }^{17}$ Mike Terry at the Witness Workshop: The Mandela Campaigns, 1 May 1999, Oxford.

${ }^{18}$ Mandela, Walter Sisulu, Govan Mbeki, Elias Motsoaledi, Andrew Mlangeni, Raymond Mhlaba, Ahmed Kathrada and Dennis Goldberg were sentenced to life in prison.
} 
and Mazisi Kuene, both from the ANC, attended World Campaign meetings and Tambo sent suggestions to the committee. ${ }^{19}$

At the end of the Rivonia Trial the focus on all the accused declined. ${ }^{20}$ Anthony Sampson points out that while Mandela was mentioned 24 times in the New York Times of 1964, he then disappeared from the newspaper for the rest of the decade, except for 1967 when Winnie Mandela was mentioned. ${ }^{21}$ Alan Brooks, the deputy Executive Secretary of AAM, noted that he could not remember a single action for Mandela when he worked for the AAM from 1967$1970 .^{22}$ At the end of the trial the ANC believed that world opinion would ensure freedom for the accused within a maximum of ten years. The South African government on the other hand believed that the men would be forgotten and that foreign supporters would abandon the cause. ${ }^{23}$

The World Campaign continued to function and took up the cases of others on trial and publicised jail conditions, but after the conclusion of the Rivonia Trial the sense of urgency declined and the committee lost support. In 1967 there was an attempt to revive the group and it was placed under the umbrella of IDAF but, despite short-term success and new initiatives, the committee continued to face problems. In 1969 discussions on the future of the committee took place between the AAM, ANC and IDAF and it was decided to keep the committee independent from any specific solidarity or liberation movement. The AAM discussed individual efforts and formed a sub-committee. The political prisoner campaign had however lost its focus and prominence. $^{24}$

\section{Southern Africa: The Imprisoned Society}

\footnotetext{
${ }^{19}$ MSSAAM1778: Committee Minutes and Papers: various minutes 28/10/1963-2/7/1964, MSSAAM1779: Newsletters and Press Releases: including The World Committee, 9 Jan. 1963, 'Report from Prison’, 22 Nov. 1963 ; Mayibuye: transcribed oral collection, 'Bernstein interview with Abdul Minty', pp. 163-90.

${ }^{20}$ Rhodes House, Oxford, Africa Bureau (MSSAfr) 1681: Box 188, file 3, item 1: Mary Benson speech to UN; J. Johns \& R. Hunt Davis jr (eds), Mandela, Tambo, and the African National Congress. The Struggle Against Apartheid (Oxford, Oxford University Press, 1991), pp. 141-2.

${ }^{21}$ Sampson, Mandela, p. 259.

${ }^{22}$ Alan Brooks at Mandela Witness Workshop, 1 May 1999, Oxford; MSSAAM 941: SA Freedom News; MSSAAM943: Various ANC Publications; R. First, No Easy Walk to Freedom: Articles, Speeches, and Trial Addresses of Nelson Mandela (London, Heinemann, 1965); Nelson Mandela: The Struggle is My Life (London, IDAF, 1978); M. Benson, Nelson Mandela (Middlesex, Penguin, 1986); F. Meer, Higher than Hope: The Authorised Biography of Nelson Mandela (Johannesburg, Penguin, 1988).

${ }^{23}$ A. du Preez Bezdrop, Winnie Mandela: A Life (Cape Town, Struik, 2003), pp. 124-7.

${ }^{24}$ MSSAAM43: National Committee Minutes, 1960-81; MSSAAM1778: Committee minutes and papers: various minutes 14/9/1964-25/3/1970.
} 
In 1973 the focus on political prisoners was revived. Alfred Nzo of the ANC approached Reddy and the UN Special Committee and suggested that the anniversary of the Rivonia arrests be observed. Reddy, however, deemed it better to celebrate the tenth anniversary of the 11 October UN Resolution, which he felt was a more positive event to remember. The Resolution also focused on all the Rivonia accused, thus including Mandela who was not arrested along with the others. ${ }^{25}$ At the same time the UN Special Committee published a survey on maltreatment and torture in South Africa for the period 1963-1972. ${ }^{26}$ The initiative was further prompted by the trial, in South Africa, of six ANC men and by a resolution at the International Trade Union Conference Against Apartheid in June 1973. ${ }^{27}$ In August the UN Special Committee chairman, Edwin Ogebe Ogbu, called for the commemoration of the UN Resolution. ${ }^{28}$ The next month an AAM memo indicated the revival of the focus on political prisoners. It advertised the period 11 October to 10 December 1973 as a period to launch campaigns, the first commemorating the UN Resolution and the latter the $25^{\text {th }}$ anniversary of the adoption of the Universal Declaration of Human Rights. The AAM, supported by trade unions, the National Union of Students (NUS) and other concerned groups, organised a conference on 8 December 1973 entitled 'Southern Africa: The Imprisoned Society'. As a result of the conference the SATIS committee came into being, run under the auspices of the AAM with members from IDAF and other solidarity and interested groups. ${ }^{29}$

The timing of the launch coincided with developments in the UK. In August 1969 the British Army entered Northern Ireland leading to the regeneration of 'guerrilla conflict between the IRA [Irish Republican Army] and British Army'. ${ }^{30}$ In the first half of 1971 twenty people were killed while over 454 civilians were injured. The violence led to the introduction of internment without trial in August 1971 when 342 men were arrested. Interrogation resulted in allegations of torture and two committees looked into the situation. The Parker Report was published in March 1972 while a minority report by Lord Gardiner uncovered the use of

\footnotetext{
${ }^{25}$ MSSAAM1362: Correspondence/ Papers OAU, 1971-93: Free Mandela Campaign memories, no author.

${ }^{26}$ D. Foster, D. Davis \& D. Sandler, Detention \& Torture in South Africa (London \& Claremont, James Currey, 1989), p. 84; The conference, in Geneva, was organised by the Workers' Group of the ILO Governing Body in cooperation with the UN Special Committee.

${ }^{27}$ MSSAAM2201: Anti-Apartheid News: April 1973.

${ }^{28}$ MSSAAM1362: Correspondence/ Papers OAU, 1971-93: UN Press Release, 17 Aug. 1973.

${ }^{29}$ MSSAAM1795: SATIS Minutes, 1974-1980: 8/2/1974; MSSAAM1802: General Correspondence: 1973-1980: AAM General letter 4/10/1973; 'South Africa: The Imprisoned Society’ Sechaba (1974).

${ }^{30}$ M. O’Boyle, 'Torture and Emergency Powers Under the European Convention on Human Rights: Ireland v. The UK’ The American Journal of International Law, 71, 4 (October, 1977), p. 674.
} 
techniques contrary to domestic law and deemed morally unjustifiable. Prime Minister Edward Heath stopped the interrogation methods, leading to a flood of allegations of torture, investigations, and the internationalisation of the issue. ${ }^{31}$ Detention and torture became especially sensitive issues in the UK.

In January 1974 SATIS held its first meeting and decided to contact other concerned groups to sponsor or participate in the committee, including the British Council of Churches (BCC), Trade Union Congress (TUC), UN Association (UNA), Amnesty International, and other black action, political and student movements. The AAM's political prisoners committee was integrated into SATIS. Representatives from these affiliates, as well as South Africans Fred Carneson and Sonia Bunting of the South African Communist Party (SACP) who came to play an active role in SATIS, attended the first meeting. This emphasises the important networks that were established as a result of the focus on prisoners and human rights. Carneson left SATIS at the end of 1974, and during 1975 another South African, Desmond Starrs, took over as SATIS chairman. In the same year Mike Terry, previously NUS Secretary (1971-1973) became AAM Executive Secretary, a position which he held until 1994. He also joined the SATIS committee. ${ }^{32}$

The SATIS committee felt that while political trials had been the focus for many years, once prisoners were imprisoned they were forgotten about and campaigns stopped. It believed that a new tactic of personalising campaigns around individuals would benefit all prisoners and agreed to concentrate on specific cases. SATIS launched in March 1974, with public meetings, newspaper publicity, street collections, and a petition. It hoped to encourage interested parties to take up the campaign for a specific prisoner and circulated biographies, dock statements and other material previously produced by the AAM, IDAF and UN on legislation and prisoners. Among the initial prisoners mentioned were Nelson Mandela, Robert Sobukwe, Bram Fischer (lawyer for the Rivonia Trial and imprisoned SACP leader), and Andimba Herman Toivo ja Toivo, the co-founder of the South West African People’s Movement (SWAPO) incarcerated since $1966 .^{33}$

\footnotetext{
${ }^{31}$ Ibid., pp. 674-80.

${ }^{32}$ MSSAAM1795: SATIS Minutes, 1974-1980: 23 Jan. 1974, 27 Oct. 1975 \& 14 April 1986; MSSAAM1802: General Correspondence: 1973-1980, AAM General letter 4/10/1973; Luthuli House ANC Collection, Johannesburg: ANC/UK/Ireland Mission: AAM, Series II: Campaigns, Box 8, Folder 9, SATIS.

${ }^{33}$ MSSAAM1795: SATIS Minutes, 1974-1980: 8/2/1974.
} 
It is clear that the initial focus of the campaign was not on Mandela as SATIS was concerned with political prisoners in general. However, the climate of interest led to student and local AAM groups adopting Mandela’s cause. Howard Smith, a student AAM member, discussed how in the early 1970s, before the AAM and ANC elevated Mandela symbolically, there were moves among students to honour him. ${ }^{34}$ Mike Terry remembered that:

the first discussion I ever had about a campaign for Mandela's release was with two NUSAS [National Unison of South African Student] leaders, Paul Pretorius and Neville Curtis, who came to London in 1971. Their idea was that NUSAS should try to do something on the primarily English-speaking campuses in South Africa, for the tenth anniversary of Mandela's arrest, August $1962 .^{35}$

Maharaj recalled that when he was in London in 1977 the focus was still on 'all political prisoners'. ${ }^{36}$

The formation of SATIS was reported on in the ANC publication Sechaba in April 1974. An article discussed the December conference where IDAF informed participants on the scale of detention and imprisonment in South Africa and statistics were examined. It reported that in the period 1963-1967 an estimated 2400 were detained without trial and that by 1973, 22 people had died in detention. Sechaba also reported on student/AAM protests for prisoners outside South Africa House and on the 'Mandela particle', the first honouring of Mandela in the 1970s. The particle was discovered at Leeds University and was classified as the heaviest elementary particle, although further research refuted this. ${ }^{37}$ Honouring Mandela by naming buildings and streets after him increased in the 1980s and became a popular way of expressing support for the struggle against apartheid. The reporting of AAM activity in the ANC publication indicates the level of cooperation between the two movements.

In order to increase support for its campaign, SATIS produced a general petition stating 'I demand the release of all political prisoners in South Africa and call on the UN to exert every pressure on the South African government to achieve this end'. By August 1974 SATIS had

\footnotetext{
${ }^{34}$ Email correspondence Smith, 25 Oct. 2004.

35 Terry at the Witness Workshop on the Mandela Campaigns (1 May, 1999, Oxford).

${ }^{36}$ Interview Maharaj, 6 Jan. 2005, Johannesburg.

37 'SATIS', Sechaba (1974).
} 
collected 30,000 signatures, which it considered a success. It organised vigils at St Martins-inthe-Field, a church on Trafalgar Square, and a demonstration on 30 June which was covered by the Observer, London Broadcasting and Capital Radio. ${ }^{38}$ The media coverage suggests that political prisoners were a popular issue as the AAM struggled to get media coverage at this time. However, public participation in 1974 suggests a drop in support, which is evidence of how difficult it was to keep an issue in the headlines - a problem the AAM experienced continually. ${ }^{39}$ By the end of the year it was clear that SATIS had managed to establish itself, and while support was difficult to sustain, the focus on political prisoners had been revived.

In 1976 the composition of SATIS began to change. In January staff changes occurred at the AAM office and Jennifer McClelland, full-time AAM Field Officer, suggested that the AAM office make more of the decisions regarding SATIS campaigns and organisation. Terry agreed to this suggestion because IDAF found it difficult to send representatives to meetings and was no longer playing as active a role. However, while SATIS increasingly came under the control of the AAM, IDAF continued to participate. In March Rica Hodgson, a South African exile, joined SATIS on behalf of IDAF. As a result of a drop in support, the AAM resolved to make SATIS's purpose clearer to those outside the movement and agreed that it should get a permanent section in the AAM's monthly publication, the Anti-Apartheid News, to discuss its actions. The newspaper became an important way of advertising and detailing SATIS campaigns. SATIS also recognised that it was not getting as much support as it had hoped from groups sympathetic to the AAM. It decided to emphasise its focus on human rights and its connection with the AAM which had a better developed support base. ${ }^{40}$ Coverage in the Anti-Apartheid News helped to establish more clearly the link between the AAM and SATIS.

At the same time, SATIS approached the liberation movements regarding forming links with groups inside South Africa and about an 'Emergency Campaign' highlighting police brutality in South Africa. Strategies were discussed with the ANC, SACTU, AAM, IDAF and some former political prisoners. The choice of groups to discuss the campaign with suggests that SATIS was moving closer to the ANC and its allies. The Emergency Campaign began well with pickets and petitions against continued imprisonment and harsh conditions. By mid-August

\footnotetext{
${ }^{38}$ MSSAAM1795: SATIS Minutes, 1974-1980: 8 Feb. 1974, 5 June1974, 24 June 1974, 12 Aug. 1974.

${ }^{39}$ MSSAAM1795: SATIS Minutes, 1974-1980: 16 Oct. 1974, 4 Nov. 1974; MSSAAM1802: General Correspondence, 1973-1980, various letters to church leaders, 1974.

${ }^{40}$ MSSAAM1795: SATIS Minutes, 1974-1980: 21 Jan. 1976, 18 Feb. 1976, 17 March 1976.
} 
SATIS had gathered over 16,000 signatures and handed the petitions to the British government. The campaign was covered in the press in South Africa and Namibia, but got limited coverage in Britain. SATIS concluded that it should try to attract representatives from more British organisations onto the committee, including the National Union of Journalists, NUS, Labour Party and Church. ${ }^{41}$ While support increased, suggesting that linking SATIS more directly to the AAM and emphasising human rights proved beneficial, the number of signatures collected was lower than in 1974.

Discussions regarding a more direct role for the ANC on the SATIS committee began in 1977 after Sonia Bunting suggested that the ANC send a representative to meetings. Sonia Bunting, wife of Brian Bunting, was a member of both SATIS and the SACP. The timing of this debate was important. It occurred at a time when support for the liberation struggle in South Africa had peaked as a result of internal political developments and the 1976 Soweto Uprising. The ANC did not initiate these internal developments, but it took action in the immediate aftermath. In this climate solidarity was particularly important for the ANC, which wanted to be recognised as an important player internally. It is clear that from this point SATIS drew closer to the ANC, a process that continued throughout the following decade. This is evident in the focus on ANC trials and actions and the close coordination with ANC activities and representatives. Internal ANC activity also increased in this period, giving SATIS and the AAM the opportunity to focus on these developments and the increased number of detainees and prisoners connected to the ANC. James Sanders suggests that the AAM was concerned about the relative invisibility of the ANC in the coverage of the Soweto Uprisings and there was a re-examination of media relations. This was another reason for the increased media coverage of ANC political prisoners and detainees from $1977 .^{42}$

Mike Terry agreed that an ANC representative would be beneficial to SATIS. In February 1977 when Albert Dlomo, an ANC ex-Robben Island prisoner, joined he expressed his hope that Dlomo would play an active role on the committee. ${ }^{43}$ The involvement of an ANC representative, without similar representation for other liberation movements such as the PAC or BCM, influenced the direction of the SATIS committee. While SATIS did not focus purely on ANC

\footnotetext{
${ }^{41}$ MSSAAM1795: SATIS Minutes, 1974-1980: 29 April 1976, 11 May 1976, 16 Aug. 1976.

42 J. Sanders, South Africa and the International Media. 1972-1979. A Struggle for Representation (London, Frank Cass Publishers, 2000), p. 97.

${ }^{43}$ Mayibuye Archive: transcribed oral collection, Bernstein interview Huddleston, pp. 149-66; Mayibuye MCA5056 (IDAF Collection) SATIS Rally.
} 
political prisoners and detainees, they did get preference over those from other political persuasions. The ANC also came to play an important role in feeding information on internal developments to SATIS, which further impacted on its choice of campaign priorities.

The evolving relationship between the ANC and AAM was visible when representatives from the two groups met in June 1977 to discuss a campaign for the 'Pretoria 12', eleven men and one woman accused of assisting the underground structures of the ANC and accused under the Terrorism Act. ${ }^{44}$ The prisoners declared that they had been tortured while in custody. ${ }^{45}$ At a minimum, they faced a sentence of five years imprisonment, but they also faced the possibility of the death sentence for conspiring to overthrow the apartheid government by violent means. The campaign was immediately reported on in the Anti-Apartheid News under "Pretoria 12 on Trial For Their Lives”. While mentioning that the campaign had been taken up by SATIS at the request of the ANC, the article discussed the Terrorism Act under which the twelve were charged, noting that Joe Gqabi (a former Robben Island prisoner) and Martin Ramokgadi were both accused of being heads of the ANC in Johannesburg. The trial was important because the state initially tried to show that the ANC had infiltrated the Soweto Student's Representative Council (SSRC). In a re-trial (after the first judge died) the prosecution dropped this line of argument. These trials were significant as they suggested a coming together of BCM and ANC elements inside South Africa, in the same way that the trial of the 'Bethal 18' trial suggested similar links between the PAC and SSRC and illustrated the complex set of relationships underground in South Africa. ${ }^{46}$ The trial of the 'Bethal 18' was not taken up by SATIS and got minimal mention in the Anti-Apartheid News, emphasising the AAM focus on ANC trials. To little avail, the AAM approached the British government regarding the 'Pretoria 12 trial'. ${ }^{47}$

The ANC's reliance on the AAM and SATIS in running the 'Pretoria 12' campaign is clear considering that even in Sechaba the organisation referred people to the AAM if they wished to get more details on the trial or be involved in the campaign. ${ }^{48}$ SATIS emphasised the fact that the initiative for the campaign came from the ANC, something it saw as giving the

\footnotetext{
${ }^{44}$ MSSAAM1795: SATIS Minutes, 1974-1980: 29 June 1977.

${ }^{45}$ The twelve were: Joe Gqabi, Martin Ramokgadi, Nelson Dlale, Elias Masinga, Paulina Mobale, Simon Moblanyaneng, Lele Motaung, Petrua Ncbabeleng, Michael Ngubeni, Jacob Seatholo, Mosima Sexwale, and Naledi Tsiki. For more details on the operations they were involved in H. Barrell, 'Conscripts to Their Age. ANC Operational Strategy, 1976-1986’ (DPhil Thesis, University of Oxford, 1993), chapter 3.

${ }^{46}$ A. Brooks \& J. Brickhill, Whirlwind Before the Storm (London, IDAF, 1980), pp. 162-4.

${ }^{47}$ MSSAAM780: Foreign \& Commonwealth Office, 1967-1981: 5 Sep. 1977.

${ }^{48}$ Sechaba (1977).
} 
campaign more credibility. The campaign continued in 1978 and the ANC issued an open letter in support of the campaign. The 'Pretoria 12' petition drew to a close in March 1978, and Oliver Tambo suggested that it would be better to hand the almost 100,000 petitions collected by SATIS to Reddy rather then taking then to the $\mathrm{UN}{ }^{49}$ This may have been in order to give the petition international, rather than purely British, standing. SATIS followed the ANC's suggestion. When the trial came to an end, Joe Gqabi was unexpectedly acquitted and went into exile. Six of the twelve accused were imprisoned, while a major benefit for the South African government was the exposure of other ANC members, giving the security police the opportunity to organise further trials, such as the ANC Treason Trial. ${ }^{50}$ SATIS viewed the campaign a success as none of the men were sentenced to death and public support for the campaign was high. It is clear that by focusing on a single issue, in this instance the Pretoria 12 Trial, SATIS was able to once again attract much greater public support. Highlighting individuals or specific trials became the centre of SATIS activity.

At the September 1977 SATIS meeting, in the midst of the 'Pretoria 12' campaign, the issue of Steve Biko's arrest, detention and death were discussed. SATIS prepared a press statement on the nature of his death but, considering Biko’s stature inside South Africa and SATIS’ focus on detention, it paid him surprisingly little attention. ${ }^{51}$ Biko's death was reported in the October Anti-Apartheid News. ${ }^{52}$ Further mention was made in November in an article on death in detention and in 'South African Police Shoot Biko Mourners' which looked more at the violence of the police than at support for Biko. ${ }^{53}$ This low level of coverage of Biko was clear again a year later when memorials for him were only reported on in a small article in the AntiApartheid News. ${ }^{54}$ It is clear that while the AAM took note of the incidents, Biko was not a SATIS or AAM focus. Furthermore, it never publicised the proceedings of the inquest into his death, although reporters followed the trial closely. ${ }^{55}$ This points further towards a preference for the ANC over support for those of other political persuasion. Nevertheless, Biko became well known internationally, especially as a result of Donald Woods' Cry Freedom and Peter Gabriel's

\footnotetext{
${ }^{49}$ MSSAAM1795: SATIS Minutes, 1974-1980: 9 Jan. 1978, 10 March 1978.

${ }^{50}$ Barrell, 'Conscripts to Their Age'; Brooks \& Brickhill, Whirlwind Before the Storm, pp. 162-4.

${ }^{51}$ MSSAAM1795: SATIS Minutes, 1974-1980: 13 Sep. 1977.

52 MSSAAM2201: Anti-Apartheid News, October 1977.

53 MSSAAM2201: Anti-Apartheid News, November 1977.

${ }^{54}$ MSSAAM2201: Anti-Apartheid News, September 1978.

${ }^{55}$ D. Woods, Biko (Harmondsworth, Penguin, 1987), pp. 226-354.
} 
1980 song. ${ }^{56}$ The use of popular culture in publicising individuals was clearly powerful and was adopted by the AAM in the Mandela Campaign, which again brought the focus towards the ANC.

The real focus on Mandela began in 1978 when he turned sixty years old. At a SATIS meeting Garth Strachan, a South African ANC supporter, AAM member, and personal assistant to Maharaj, suggested a birthday card for Mandela. ${ }^{57}$ SATIS approached the London ANC with the suggestion. The AAM, ANC and SATIS met in March to discuss the issue, and the ANC gave its approval to the Mandela initiative. This interaction emphasises the role that the ANC played in determining SATIS campaigns. At the same meeting the ANC asked that SATIS develop a campaign around Solomon Mahlangu who was a young ANC/MK man sentenced to death. The ANC asked for AAM help in order to get the issue taken to the UN. ${ }^{58}$

SATIS immediately responded to the ANC's request and began to focus on Mahlangu while Mandela's birthday was an issue taken up by the AAM as a whole. The Mahlangu campaign was important for the ANC because Mahlangu was part of the Soweto generation of youth, many of whom were conscientised by BCM, who had left South Africa after the Soweto uprising and gravitated towards the ANC in exile. Mahlangu was part of early ANC reinfiltration of South Africa, and it was important for the ANC to show both the international community and those inside South Africa that it was taking action and that the Soweto generation was returning home. SATIS explained in the Anti-Apartheid News that Mahlangu was convicted of shooting two mechanics inside South Africa, which he denied doing. The mechanics had in fact been killed by another guerrilla, Mondy Motloung, who was beaten by police until he had brain damage. The paper described Mahlangu as a patriot, and the South African regime as illegitimate. $^{59}$

While the Mahlangu campaign was not successful in saving Mahlangu's life - he was executed in April 1979 - it did succeed in drawing in British public and government support. Initially David Owen, the Minister of State at the Foreign and Commonwealth Office and later Foreign Secretary, was reluctant to get involved, arguing that the British government had no

\footnotetext{
${ }^{56}$ R. Attenborough (director), Cry Freedom, 1987.

${ }^{57}$ R. Kasrils, Armed and Dangerous, (Jeppestown, Jonathan Ball, 1998) pp. 121, 258.

${ }^{58}$ MSSAAM1795: SATIS Minutes, 1974-1980: 16 Feb. 1978, 10 March1978, 9 May 1978, 12 June 1978.

${ }^{59}$ MSSAAM2201: Anti-Apartheid News, April 1978; MSSAAM949: Miscellaneous ANC Papers: 'South African Prisoners, Torture and Detention'.
} 
formal standing to question the judgement of a South African court. ${ }^{60}$ However by October 1978 Owen had asked that the AAM keep him informed on developments and he associated the British government with an appeal to the South African government made by Shridath Ramphal, the Commonwealth Secretary General. ${ }^{61}$ By the end of the year the British government had called for clemency. ${ }^{62}$ These developments suggest that focusing on the death penalty (which was outlawed in the UK in 1965) and human rights issues more broadly had a particular effect on British opinion. Mahlangu claimed not to have killed the men in question and also raised issues regarding police torture and the independence of the judiciary. The change in government opinion indicates that international views, expressed here through the Commonwealth, and public protest affected the government's stand. For SATIS, it was a great achievement to succeed in attracting government support, even if it was limited to one issue.

The Mahlangu campaign was not just a political campaign to increase support for the struggle, but a campaign focused on an individual. It showed how the AAM focused on human rights violations in order to attract greater public support, a strategy that proved successful. As Dugard noted:

After all it was not South Africa's race laws, but its security laws, that prompted the Security Council of the United Nations to order mandatory sanctions for the first time ever against a member state, when it directed states to impose an arms embargo on South Africa ${ }^{63}$

It is clear that the AAM and SATIS were able to attract greater support for the anti-apartheid struggle when focusing on human rights issues. The British government was reluctant, even under Labour, to offer direct support to the liberation struggle. Similarly, much of the British public did not involve itself in general anti-apartheid campaigns, possibly because they felt they did not have enough knowledge on political issues. However, the AAM was able to attract support for campaigns focused more directly on human rights issues. While completely

\footnotetext{
${ }^{60}$ MSSAAM1805: Correspondence with British government, letter 15/5/1978; MSSAAM780: FCO, 1967-1981: 5 July 1978.

${ }^{61}$ MSSAAM1795: SATIS Minutes, 1974-1980: 16/11/1978; MSSAAM1805: Correspondence with British government, 15 May 1978.

${ }^{62}$ MSSAAM2202: Anti-Apartheid News, January/February 1979.

${ }^{63}$ C. R. J. Dugard, 'A Triumph for Executive Power - an Examination of the Rabie Report and the Internal Security Act 74 of 1982’ South African Law Journal 99 (1982), pp. 589-604 quoted in Foster, Davis \& Sandler, Detention \& Torture, p. 2.
} 
separating political issues from human rights issues was neither possible nor pragmatic, a greater focus on the human element proved particularly successful. Similarly, the Mandela Campaign, as we shall see below, focused on an individual. Once support had been harnessed for his release, it was possible to expand the campaign to include discussions on political ideology and the standpoint of the ANC. Furthermore, analysis of the campaigns organised by SATIS in the 1970s, as well as their mode of organisation, reflects growing AAM and SATIS support for the ANC over other liberation movements. The ANC formed closer ties with the AAM than any other liberation movement did, and in return the focus of political prisoner campaigns shifted towards the ANC. Through these campaigns, the ANC and its political ideology were publicised.

\section{Mandela's Sixtieth Birthday}

The international campaign which focused on Nelson Mandela became one of the biggest and most successful AAM initiatives ever embarked on. The campaign succeeded in, not only making Mandela well known to the majority of the British population, but also in increasing support for the ANC and for the struggle against apartheid. The success of the campaign rested largely of the fact that it was able to attract supporters from different political persuasions, those not politically aware, and the youth. ${ }^{64}$

The 1978 celebration for Mandela’s sixtieth birthday signalled a new focus on him, although it was only in the 1980s that the campaign really took root as a focal point of international anti-apartheid activity. The AAM gave direction to the celebrations. ${ }^{65}$ The AAM pamphlet calling on people to join the commemoration spoke of Mandela's life and lifelong struggle to free the people of South Africa. The pamphlet stated that the international community should see the day as a 'day which symbolises the courage and determination of the black people of South Africa to overthrow apartheid', thus using Mandela to represent not only prisoners but all those fighting apartheid and the ANC. The AAM called Mandela the 'leader of South Africa's liberation movement', and made it clear that South Africa could experience no real change or

\footnotetext{
${ }^{64}$ MSSAAM1932: Gallup Poll.

${ }^{65}$ MSSAAM1362: Correspondence/ Papers OAU, 1971-1993: Free Mandela campaign memories, no author; Terry at Mandela Witness Workshop, 01/05/1999, Oxford; MSSAAM43: National Committee Minutes, 1960-1981, 1 July 1978.
} 
peace as long as the real leaders were in prison. In this connection Walter Sisulu and Govan Mbeki were also mentioned. ${ }^{66}$

The initial campaign focused on portraying Mandela as intelligent, a natural leader and a victim of the South African regime, and also as important and influential - both within the ANC and in the wider South African and international context. Through depicting Mandela in this way, he became an accepted and powerful symbol of the struggle against apartheid. In the first instance, pamphlets showed Mandela as an ordinary person, discussing his marriage to Winnie Mandela and her harrassment by the South African government. They were also keen to emphasise the fact that he was an educated attorney. Mandela’s important position was emphasised through discussing the international campaign at the time of his imprisonment, his role in the decision by the ANC to move to armed struggle 'when all other channels of peaceful protest had been barred', and his role as a key figure since the 1940s. The fact that he was part of small group of prisoners kept separately from the other prisoners was stressed, together with his being a founding member of the ANC Youth League, the Volunteer-in-Chief during the Defiance Campaign and accused in the Treason Trial. ${ }^{67}$ The AAM emphasised Mandela's rise to prominence in the period before his capture and trial. ${ }^{68}$

It is clear that the Mandela campaign focused on human rights as well as political issues. By emphasising Mandela’s incarceration and police brutality against his wife, broader public support was harnessed. However, at the same time his words and actions were used to publicise the actions and ideology of the ANC and to inform people about apartheid. It was also through Mandela that the armed struggle, which remained a contentious issue internationally, could be addressed more easily.

For the AAM, the Mandela Campaign played an important role in increasing mass popular support and participation. In the early 1960s the AAM concentrated on the British government's South Africa policy and on bringing about change through influencing the government. The importance of popular support however became clear, and the AAM shifted its focus. ${ }^{69}$ The AAM continued to argue that changing government policy was important, but it believed change would be brought about through the mobilisation of the wider population. The

\footnotetext{
${ }^{66}$ MSSAAM1908: Nelson Mandela's 60 ${ }^{\text {th }}$ Birthday; e-mail contact Smith (25 Oct. 2004).

${ }^{67}$ MSSAAM1908: Nelson Mandela's 60 ${ }^{\text {th }}$ Birthday.

${ }^{68}$ MSSAAM13: Annual Report 1979-1980.

${ }^{69}$ MSSAAM13: Annual Report 1964, 1965 \& 1968-1969.
} 
Mandela campaign arguably gave the AAM access to a greater section of the British population than any previous campaign because it was not a radical issue. In 1978 SATIS requested that people send birthday cards to Mandela and messages of support to Winnie Mandela. These actions had the dual role of making the AAM better known and helping the ANC by showing the South African government the extent of international sympathy. The AAM also asked supporters to urge the British government to act. This illustrates how the AAM expected mass support to influence government policy as the government would face criticism from various angles. The AAM also called on people to join in other AAM campaigns or to contribute financially, suggesting that it used this popular campaign to increase its general support. ${ }^{70}$

Despite the shift in focus, the AAM continued to work in the political sphere. A birthday card for Mandela was passed around the cabinet and many members signed it. However, when the South African embassy refused to accept the card on 18 July, the date of Mandela's birthday, Prime Minister James Callaghan sent greetings to Mandela from the floor of the House of Commons. ${ }^{71}$ This was the first instance of such an action by the British government and was a noteworthy achievement for the AAM. A meeting for Mandela's birthday was held that evening in the Grand Committee Room of the House of Commons. It was organised together with the ANC, IDAF and UN Special Committee and was coordinated by Mike Terry (AAM), Francis Meli (ANC) and Toine Eggenhuizen (IDAF). Speakers included Leslie Harriman (UN Special Committee), Canon Collins (IDAF), Mary Benson and Francis Meli (ANC). The event was a significant turning point, with the support of around 300 people. $^{72}$

The 1978 birthday celebrations were also a success on a public level. Over three thousand birthday cards were sent to Mandela and together the AAM and ANC organised pickets and gatherings across the country to coincide with the day. A picket was held outside South Africa House on 18 July and IDAF published a collection of Mandela's speeches and organised a photo exhibition using images from the book. ${ }^{73}$ Mandela's image was important as nobody had up to date photos of him. Throughout the Mandela campaign the images used were therefore stylised

\footnotetext{
${ }^{70}$ MSSAAM1908: Nelson Mandela's $60^{\text {th }}$ Birthday; A. Sampson, Mandela. The Authorised Biography (London 1999), pp. 296-7.

${ }^{71}$ Although the greetings are not mentioned Callaghan policy discussed in K. O’Morgan, Callaghan. A Life (New York, Oxford University Press, 1997), pp. 152-9, 313-27, 458-9; B. Donoughue, Prime Minister. The Conduct of Policy Under Harold Wilson and James Callaghan (London, Jonathan Cape, 1987).

${ }^{72}$ MSSAAM68: Executive Committee Minutes, 1978-1985, 18 June 1980; MSSAAM1908: Nelson Mandela's $60^{\text {th }}$ Birthday; MSSAAM1909. Mandela Campaign 1980-1982; Terry at Mandela Witness Workshop, 01 May 1999, Oxford.

${ }^{73}$ IDAF, Nelson Mandela.
} 
and based on a younger Mandela and pictures taken before or in his early incarceration. Nixon argues that it was partly because the same photos of Mandela were re-circulated throughout the campaign that his image became so prominent. ${ }^{74}$ Student groups gave their support to the birthday celebrations at the annual NUS/AAM Conference by signing a declaration supporting the struggle. ${ }^{75}$ On his birthday the Times called Mandela 'the colossus of African nationalism' showing a marked change to a few years earlier when he was all but forgotten. ${ }^{76}$

Oliver Tambo gave his personal support to the birthday celebrations and spoke of Mandela as among the 'best sons and daughters of our people' and the ANC representative of the generation of 1943 that formed the Youth League. He spoke of the transformation of the ANC falling on the shoulders of Mandela and Walter Sisulu and described how Mandela had moved the struggle into the hands of the masses, formed bonds with Indians and Coloureds and challenged racist rhetoric. These discussions emphasise how the image of Mandela was used to popularise the ideology and position of the ANC above that of other liberation movements, and even to criticise other anti-apartheid political standpoints. Tambo concluded that Mandela's outstanding qualities as 'patriot and revolutionary have placed him where he is today, in the front ranks of the authentic leadership of the people of South Africa and a respected world statesman. ${ }^{77}$ The rhetoric used by Tambo was utilized by the AAM in future campaigns. Both the ANC and AAM used Mandela as a representative for the general beliefs of the ANC, such as non-racialism. Thus, by focusing on Mandela the AAM was able to inform the British public on the ideological standpoint of the ANC, contradicting the South African government definition of the ANC and Mandela as terrorist. Tambo's speech highlights how the Mandela campaign was a way of showing the ANC to the British public in a more positive light.

During the next decade, in developing the Mandela campaign, the AAM made use of popular culture, music and media, thus drawing in even more diverse support than the focus purely on human rights could have done. This in turn popularised Mandela, turning him into a symbol of the struggle against apartheid and repression. As Mandela became accepted as a future South African leader, the ANC increasingly became recognised internationally as the liberation movement of choice.

\footnotetext{
${ }^{74}$ R. Nixon, 'Mandela, Messianism and the Media' Transition, 51 (1991), pp. 42-55.

${ }^{75}$ MSSAAM1908: Nelson Mandela's $60^{\text {th }}$ Birthday.

${ }^{76}$ du Preez Bezdrop, Winnie Mandela, p.200.

${ }^{77}$ MSSAAM1908: Nelson Mandela's $60^{\text {th }}$ Birthday.
} 


\section{Conclusion}

By the end of the 1970s the AAM focus on human rights, political prisoners and detainees was well developed. In the final decade of apartheid, as both resistance and repression increased, campaigns focusing on trials, torture and incarceration gained prominence. In the 1980s the AAM turned its attention to the Mandela campaign, while SATIS continued to focus on prisoners more generally. The Mandela campaign attracted a high level of sustained public interest and played an important role in dealing with international lack of certainty regarding what change would bring about in South Africa. By focusing on the ANC, through Mandela, international uncertainty regarding what the ANC represented ideologically decreased and ANC ideals became better understood. While criticism of the armed struggle remained a problem, a greater percentage of the British population came to support an end to apartheid. The Mandela campaign also impacted on those fighting apartheid inside South Africa - through expressions of solidarity it showed political prisoners that they were not forgotten. The campaign also managed to attract broad political support, both in Britain and among South African exiles of different political orientations. $^{78}$ The call for Mandela’s release was not considered contentious.

Furthermore, through commenting on security legislation, imprisonment, detention, torture and death sentences the AAM was able to increase criticism of the South African regime. Issues of human rights and compliance with international law drew in support from a variety of world bodies, governments and interested organisations. SATIS compared the South African situation to international norms and publicised international decrees which forbade torture. $^{79}$ These campaigns proved effective in attracting support from those who preferred not to become politically aligned but who were socially aware, and provided the basis for the AAM to establish more diverse networks. However, while solidarity campaigns which focused attention of human rights and individual prisoners proved highly successful in increasing support for the struggle against apartheid, these campaigns were not non-aligned. Through its close relationship with the ANC, and by focusing on prisoners and detainees connected to the ANC, the AAM also brought the focus towards the ANC and publicised it above other anti-apartheid organisations.

\footnotetext{
78 Telephone interview David Hemson, 11 Nov. 2004, discussing the AAM, ANC and tension post-1976; S. M. Davis, Apartheid's Rebels. Inside South Africa's Hidden War (New Haven, Yale University Press, 1987), p. 49.

${ }^{79}$ Foster, Davis \& Sandler, Detention \& Torture, p. 172.
} 
The ideology, aims and aspirations of the ANC therefore became better understood in Britain.

Finally, through focusing on the use of violence by the South African regime, the solidarity

movement was able, to some extent, to reduce criticism of the armed struggle.

\section{GeneVIEVE KLEIN}

St Antony's College and History Faculty, Oxford University, and Department of Historical and Heritage Studies, University of Pretoria, Level 18, Humanities Building, University of Pretoria, Lynnwood Road, Hillcrest, 0002, Pretoria. E-mail:

glklein@ mweb.co.za 